\title{
A Review of the Leptin Hormone and the Association with Obesity and Diabetes Mellitus
}

\author{
Aldeam Facey ${ }^{1 *}$, Lowell Dilworth ${ }^{2}$ and Rachael Irving ${ }^{1}$ \\ ${ }^{1}$ Department of Basic Medical Sciences, University of the West Indies, Mona Kingston 7, Jamaica \\ ${ }^{2}$ Department of Pathology, University of West Indies, Mona Campus, Jamaica \\ *Corresponding author: Facey A, Seattle Science Foundation, Seattle, WA, USA, Tel: +1-206-334-8399; E-mail: vvoin@outlook.com
}

Received Date: February 06, 2017; Accepted Date: March 01, 2017; Published Date: March 08, 2017

Copyright: () 2017 Facey A, et al. This is an open-access article distributed under the terms of the Creative Commons Attribution License, which permits unrestricted use, distribution, and reproduction in any medium, provided the original author and source are credited.

\begin{abstract}
Leptin is a protein hormone that regulates food intake. It is secreted by the adipocytes and contains 167 amino acids. The hormone signals the hypothalamus and is released to reduce the desire for food thereby controlling appetite. Research shows that diet-induced obesity results in leptin resistance, so while the level of leptin may be high, it is ineffective. Leptin is also increased in type 2 diabetes mellitus which is strongly associated with obesity and insulin resistance. While leptin may be elevated in both diabetes and obesity, it is not the cause of either disease. It has been suggested that leptin mediates insulin resistance and as such may be a possible treatment for insulin resistance. Diet induced leptin resistance can be reversed through dietary changes and its administration can be effective in combating insulin resistance. Leptin levels may also decrease with increased exercise. The pathophysiology involving leptin resistance is unclear. More leptin studies are needed as it may be an unexplored treatment for diabetes and may be able to provide a more detailed understanding of the disease.
\end{abstract}

Keywords: Leptin; Obesity; Diabetes; Insulin resistance

\section{Introduction}

Leptin which contains 167 amino acids, was discovered in 1994. It is a hormone secreted by adipocytes and has been found to regulate the intake of food $[1,2]$. Leptin aids in the regulation of eating behavior through central neuroendocrine mechanisms [2]. It is structurally similar to cytokines and contains an intrachain disulphide bond which has functional significance [3]. Leptin is produced primarily by white adipose tissues and released as a 16 kilo Dalton [kDa] protein [3]. This circulating leptin correlates positively with leptin mRNA and protein levels in adipose tissue [3].

The hormone regulates neuroendocrine function and energy expenditure [1], and has since provided significant insights in obesity [4].

The hypothalamus senses the nutritional state of the body through signaling provided by the leptin hormone [5]. Leptin decreases the intake of food through the upregulation of neuropeptides such as $\alpha$ melanocyte-stimulating hormone, which is known to be anorexigenic [5]. It concurrently downregulates orexigenic factors such as neuropeptide Y [5]. Obesity can be caused by genetic defects in anorexigenic signaling, such as mutations in the melanocortin- 4 or leptin receptors [5]. The administration of leptin in humans and mice induces the reduction of excessive eating and obesity [6]. Obesity, however is associated with high leptin levels which can indicate leptin resistance in obese individuals [6].

Leptin works in contrast to ghrelin, a peptide primarily produced by the stomach which stimulates the appetite [7]. An increase in hunger is directly proportional to an increase in the ratio of ghrelin to leptin [7]. Clinical studies show that leptin levels increase with sleep $[7,8]$. Research also found that ghrelin levels are inversely related to sleep duration [8].

\section{Leptin and obesity}

Obesity is a greater proportion of body fat in relation to lean mass which is significant enough to negatively affect health [9]. The disease can be caused by lifestyle or hereditary influences. Obesity is hereditary primarily due to genetic factors [10]. In mouse, the gene which causes obesity was sequenced in 1994 [10]. Mutation of the gene which causes obesity, results in increased food intake, elevated insulin and significant obesity in non-insulin dependent diabetes mellitus [10]. The mutated gene causes the production of inactive leptin or no leptin [10]. Such mutations are however very unlikely in humans [10]. In a more recent study, lack of leptin in mice has been found to cause severe obesity because of increased food intake and reduced energy expenditure [11]. This has similarly been proven in humans [12]. The leptin deficient mice also develop hyperinsulinemia, often times leading to diabetes mellitus [11]. These effects can be reversed through the administration of the Leptin [13]. This adipocyte-specific protein provided the first links to the body's system regulating body weight [14]. Even though leptin generally increases with adiposity, it was found that at each BMI level there is variability in serum leptin concentration. This suggests that there are differences in its secretion rate from fat [15].

Obesity is not only influenced by lack of leptin but also leptin resistance [16]. Leptin has been proven to increase with increasing adiposity in humans and rodents [16]. Given that the presence of leptin reduces food intake and body weight, elevated levels of leptin in obese persons is viewed as leptin resistance [17]. In these cases, humans lack the responsiveness to the appetite reducing effects of leptin [9]. The effects of leptin resistance are however reversible. If the fat content of obese mice is reduced, the mice will recover leptin sensitivity and glycemic control [9]. It is believed that decreased leptin sensing in the melanocortin circuits influences the pathology of leptin resistance [9]. Research done on mice found that the diet induced resistance to leptin occurs in stages [18]. In the first stage, in response 
to high fat diet, the mice were sensitive to exogenous leptin. The second stage conveyed a reduced food consumption, increased leptin production and central leptin sensitivity. The final stage conveyed increased food intake and reduced central leptin sensitivity [18]. The leptin resistance caused by high fat diet results from a defect in access to sites of action in the hypothalamus, which significantly decreases the ability of peripheral leptin to activate hypothalamic signaling [19]. The resistance is also caused by an intracellular signaling defect in leptin-responsive hypothalamic neurons [19]

Leptin has also been associated in the disease atherosclerosis. The thickening of the intima and tunica media is believed to be a marker of the initial stage of atherosclerosis, before symptoms arise [20]. Researchers showed that serum leptin concentrations independently and positively correlated with the intima-media thickness of the common carotid artery [20]. This suggests that increases in leptin concentration is a risk factor for the development of atherosclerosis [20].

Research has found that diet can reduce the levels of leptin [21]. The Palaeolithic diet was found to have a more significant reducing effect on fasting leptin concentration [21]. The reduction in leptin, however, concurs with reduction in weight during the diet [21]. The diet induced reduction in leptin may be due to a concurring loss of fat [21].

\section{Leptin and diabetes}

Type 2 diabetes is expected to afflict 300 million persons by 2020 [22]. Not many studies have assessed a direct relationship between leptin concentration and diabetes [23]. Research has however shown that leptin levels are generally higher in persons with diabetes mellitus except when the data is adjusted for body mass index [23]. Leptin has the ability to improve or coonversely induce insulin resistance [24]. This hormone is also known to mediate the release of insulin from pancreatic $\beta$ cells [24]. Research shows that leptin can be therapeutically useful in the treatment of lipoatrophic diabetes [25]. It is interesting to note that obesity is directly associated with insulin resistance and the development of diabetes mellitus in humans [24]. Given that obesity can be a result of leptin resistance, leptin resistance is likely to be involved in the development of the disease. Like Leptin resistance, leptin deficiency is significant in the pathogenesis of severe insulin resistance in uncontrolled insulin deficient diabetes mellitus [26].

It can however be noted that leptin signaling in neurons can be restored by overexpression of anorexigenic peptides and or repression of orexigenic peptides [27]. Food compounds such as teasaponins, reservatrol, caffeine, taurine and celastrol are able to restore the leptin signaling in neurons using the expression or repression of these peptides [27]. It was also discovered that vitamins $\mathrm{A}$ and D improves the transport of leptin across the blood brain barrier [27]. Researchers found that leptin treatment reverses diabetes in lipoatrophic mice [28]. Diet and leptin treatment should be thoroughly explored as a method of diabetes control.

\section{Leptin in athletes}

In younger elite kayakers it was observed that short-term detraining resulted in a significant increase in waist circumference, insulin and fasted leptin [29]. The magnitude of the increases in insulin and leptin was dependent on the level of inactivity, where a partially detrained athlete did not express increases as marked as were found in the totally detrained athletes [29]. A study on female athletes concluded that leptin is a possible metabolic signal that provides a link between adipose tissue, energy availability and the reproductive axis [30]. The study however found that sex hormones do not directly regulate leptin (Table 1) [30].

A study on marathon runners found that leptin levels in the runners decrease with body fat [31]. The study also found that after an energy expenditure of $2800 \mathrm{Cal}$ leptin levels decreased suggesting that strong changes in energy expenditure may regulate leptin concentrations [31].

\begin{tabular}{|l|l|l|}
\hline Year & Discovery & Reference \\
\hline 1994 & $\begin{array}{l}\text { Mice obese [ob] gene and its homolog in } \\
\text { humans, cloned. }\end{array}$ & {$[32]$} \\
\hline 1995 & $\begin{array}{l}\text { The protein product [leptin] of the ob gene was } \\
\text { purified. }\end{array}$ & {$[13]$} \\
\hline 1996 & $\begin{array}{l}\text { Leptin levels in humans vary with the time of } \\
\text { the day, peaking nocturnally. }\end{array}$ & {$[33]$} \\
\hline 1997 & $\begin{array}{l}\text { Increased leptin concentration impairs the } \\
\text { action of insulin in rat adipocytes }\end{array}$ & {$[34]$} \\
\hline 1999 & $\begin{array}{l}\text { Baseline leptin level is associated with the } \\
\text { development of diabetes in men }\end{array}$ & {$[35]$} \\
\hline 2001 & $\begin{array}{l}\text { Leptin shows therapeutic potential to improve } \\
\text { diabetes mellitus and reduce insulin } \\
\text { resistance. }\end{array}$ & {$[25]$} \\
\hline 2004 & $\begin{array}{l}\text { Leptin level increases with sleep } \\
\text { homeostasis appears to be consistent across } \\
\text { the vertebrate specie in significant in the pathogenesis of } \\
\text { insulin resistance in uncontrolled insulin- } \\
\text { deficient diabetic rats }\end{array}$ & {$[26]$} \\
\hline 2010 & {$[36]$} \\
\hline 2016 & {$[7]$} \\
\hline
\end{tabular}

Table 1: Chronology of some significant discoveries in Leptin research.

\section{Conclusion}

Leptin elevation in diabetes and obesity makes it a significant parameter to assess in clinical research studies. For years it has been known that obesity associated diabetes is linked to insulin resistance as the central basis for the association [37]. Leptin is involved in energy metabolism and changes with physical exercise. Leptin has also been found to have immunological responses [38]. Its signaling can regulate innate inflammatory responses, regulate adaptive immunity and even suppress regulatory $\mathrm{T}$ cell differentiation [38]. To date the link between insulin resistance and obesity is not clearly defined as details of the mechanism are not fully understood [37]. Further studies on leptin metabolism and mechanisms of action may be able to define or fill the gap that exists. Research can also explore leptin therapy in combination with dieting which stimulates leptin signaling as a means of controlling diabetes and obesity.

\section{References}

1. Minikoshi Y, Kim Y, Peroni OD, Fryer LG, Muller C, et al. (2002) Leptin stimulates fatty-acid oxidation by activating AMP-activated protein kinase. Nature 415: 339-343.

2. Grinspoon S, Gulick T, Askari H, Landt M, Lee K, et al. (1996) Serum leptin levels in women with anorexia nervosa. The Journal of Clinical Endocrinology and Metabolism 81: 3861-3863. 
3. Ahima RS, Flier JS (2000) Leptin. Annual Review of Physiology 62 413-437.

4. Miczke A, Pupek-Musialik D (2000) Leptin and Obesity. Pol Merkur Lekarski 8: 109-112.

5. Marzo VD, Goparaju SK, Wang L, Liu J, Batkai S, et al. (2001) Leptinregulated endocannabinoids are involved in maintaining food intake. Nature 410: 822-825

6. Cowley MA, Smart JL, Rubinstein M, Cerdan MG, Diano S, et al. (2001) Leptin activates anorexigenic POMC neurons through a neural network in the arcuate nucleus. Nature 411: 480-484.

7. Spiegel K, Tasali E, Penew P, Cauter EV (2004) Brief Communication Sleep Curtailment in Healthy Young Men Is Associated with Decreased Leptin Levels, Elevated Ghrelin Levels, and Increased Hunger and Appetite. Annals of Internal Medicine 141: 846-850.

8. Taheri S, Lin L, Austin D, Young T, Mignot E (2004) Short Sleep Duration Is Associated with Reduced Leptin, Elevated Ghrelin, and Increased Body Mass Index. PLOS Medicine 1: e62.

9. Enriori PJ, Evans AE, Sinnayah P, Jobst EE, Tonelli-Lemos L, et al. (2007) Diet-Induced Obesity Causes Severe but Reversible Leptin Resistance in Arcuate Melanocortin Neurons. Cell Metabolism 5: 181-194.

10. Sørensen TI, Echwald S, Holm JC (1996) Leptin in Obesity. British Medical Journal 313: 953-954.

11. Farooqi S, Matarese G, Lord GM, Keogh JM, Lawrence E, et al. (2002) Beneficial effects of leptin on obesity, $\mathrm{T}$ cell hyporesponsiveness, and neuroendocrine/metabolic dysfunction of human congenital leptin deficiency. The Journal of Clinical Investigation 110: 1093-1103.

12. De Luis DA, Perez Castrillon JL, Duenas A (2009) Leptin and Obesity. Minerva Medica 100: 229-236.

13. Halaas JL, Gajiwala KS, Maffei M, Cohen SL, Chait BT, et al. (1995) Weight-reducing effects of the plasma protein encoded by the obese gene. Science 269: 543-546.

14. Hassink SG, Shelow DV, Lancey E, Opentanova I, Considine RV, et al. (1996) Serum Leptin in Children with Obesity: Relationship to Gender and Development. Pediatrics 98: 201-203.

15. Maffei M, Halaas J, Ravussin E, Pratley RE, Lee GH, et al. (1995) Leptin levels in human and rodent: Measurement of plasma leptin and ob RNA in obese and weight-reduced subjects. Nature Medicine 1: 1155-1161.

16. Ahima RS, Prabakaran D, Mantzoros C, Qu D, Lowell B, et al. (1996) Role of leptin in the neuroendocrine response to fasting. Nature 382: 250-252.

17. Myers MG, Leibel RL, Seeley RJ, Schwartz MW (2010) Obesity and leptin resistance: distinguishing cause from effect. Trends in Endocrinology and Metabolism 21: 643-651.

18. Lin S, Thomas TC, Storlien LH, Huang XF (2000) Development of high fat diet-induced obesity and leptin resistance in $\mathrm{C} 57 \mathrm{Bl}=6$ ] mice. International Journal of Obesity 24: 639-646.

19. El-Haschimi K, Pierroz DD, Hileman SM, Bjorbaek C, Flier JS (2000) Two defects contribute to hypothalamic leptin resistance in mice with diet-induced obesity. The Journal of Clinical Investigation 105: 1827-1832.

20. Ciccone M, Vettor R, Pannacciulli N, Minenna A, Bellacicco M, et al (2001) Plasma leptin is independently associated with the intima-media thickness of the common carotid artery. International Journal of Obesity 25: 805-810.

21. Fontes-Villalba M, Lindeberg S, Granfeldt Y, Knop FK, Memon AA, et al. (2016) Palaeolithic diet decreases fasting plasma leptin concentrations more than a diabetes diet in patients with type 2 diabetes: a randomised cross-over trial. Cardiovascular Diabetology 15: 12-16.

22. Muoio DM, Newgard CB (2008) Molecular and metabolic mechanisms of insulin resistance and $\beta$-cell failure in type 2 diabetes. Nature Reviews Molecular Cell Biology 9: 193-205.

23. Bandaru P, Shankar A (2011) Association Between Plasma Leptin Levels and Diabetes Mellitus. Metabolic Syndrome and Related Disorders 9: 19-23.

24. Ceddia RB, Koistinen HA, Zierath JR, Sweeney G (2002) Analysis of paradoxical observations on the association between leptin and insulin resistance. The FASEB Journal 16: 1163-1176.

25. Ebihara K, Ogawa Y, Masuzaki H, Shintani M, Miyanaga F, et al. (2001) Transgenic Overexpression of Leptin Rescues Insulin Resistance and Diabetes in a Mouse Model of Lipoatrophic Diabetes. Diabetes 50: 1440-1448.

26. German JP, Wisse BE, Thaler JP, Oh-I S, Sarruf DA, et al. (2010) Leptin Deficiency Causes Insulin Resistance Induced by Uncontrolled Diabetes. Diabetes 59: 1626-1634.

27. Aragonès G, Ardid-Ruiz A, Ibars M, Suárez M, Bladé C (2016) Modulation of leptin resistance by food compounds. Molecular Nutrition \& Food Research 60: 1789-1803.

28. Reitman ML, Gavrilova O, Marcus-Samuels B, Leon LR, Vinson C (2000) Hormones: Leptin and diabetes in lipoatrophic mice. Nature 403: 850-850.

29. Liu TC, Liu YY, Lee SD, Huang CY, Chien KY, et al. (2008) Effects of short-term detraining on measures of obesity and glucose tolerance in elite athletes. Journal of Sports Science 26: 919-925.

30. Thong FS, McLean C, Graham TE (2000) Plasma leptin in female athletes: relationship with body fat, reproductive, nutritional, and endocrine factors. Journal of Applied Physiology 88: 2037-2044.

31. Leal-Cerro A (1998) Serum Leptin Levels in Male Marathon Athletes before and after the Marathon Run. Journal of Clinical Endocrinology Metabolism 83: 2376-2379.

32. Zhang Y, Proenca R, Maffel M, Barone M, Leopold L, et al. (1994) Positional cloning of the mouse obese gene and its human homologue. Nature 372: 425-432.

33. Sinha MK, Ohannesian JP, Heiman ML, Kriauciunas A, Stephens TW, et al. (1996) Nocturnal rise of leptin in lean, obese, and non-insulindependent diabetes mellitus subjects. Journal of Clinical Investigation 97: 1344-1347.

34. Ertl J, Gerl M, Muller G, Preibisch G (1997) Leptin Impairs Metabolic Actions of Insulin in Isolated Rat Adipocytes. Journal of Biological Chemistry 272: 10585-10593.

35. Mcneely MJ, Boyko EJ, Weigle DS, Shofer JB, Chessler SD, et al. (1999) Association between baseline plasma leptin levels and subsequent development of diabetes in Japanese Americans. Diabetes Care 22: 65-70.

36. Michel M, Page-Mccaw PS, Chen W, Cone RD (2016) Leptin signaling regulates glucose homeostasis, but not adipostasis, in the zebrafish. Proceedings of the National Academy of Sciences 113: 3084-3089.

37. Khan BB, Flier JS (2000) Obesity and insulin resistance. The Journal of Clinical Investigation 106: 473-481.

38. Naylor C, Petri WA (2016) Leptin Regulation of Immune Responses. Trends in Molecular Medicine 22: 88-98. 